\title{
Evaluating thermal effects of internal courtyard in a tropical terrace house by computational simulation
}

\begin{abstract}
Thermal comfort conditions in residential buildings vary according to the designs, modifications of the house and adaptations of the occupants. The purpose of this paper is to examine thermal performance of terrace housing in tropical climate by exploiting internal courtyard. A case study of a terrace house was chosen, where field measurement was conducted during a three-day recording in naturally ventilated spaces of the house. Results from field measurement were used to develop a baseline model for computational experiment. Subsequently, the effects of introducing an internal courtyard on thermal comfort performance of the building were investigated using ECOTECT software. The results from simulation analysis indicate that, applying internal courtyard in the terrace house will improve natural ventilation and thermal comfort in spaces with openings to the outside environment. It shows that the influence of the internal courtyard on the thermal condition has a strong reliance on the envelop openings. This study suggests that the internal courtyard of a terrace house can affect improvements in thermal conditions of the courtyard's surrounding spaces, provided sufficient and efficient openings with shading devices are suitably incorporated.
\end{abstract}

Keyword: Thermal comfort; Terrace house; Internal courtyard; Heat gain; Tropical climate 